ENZYMATIC ACTIVITY OF CATECHOL 1,2-DIOXYGENASE AND CATECHOL 2,3-DIOXYGENASE PRODUCED BY Gordonia polyisoprenivorans

Andréa Scaramal Silva e Flávio Anastácio de Oliveira Camargo

Departamento de Ciência do Solo, Universidade Federal do Rio Grande do Sul, Av. Bento Gonçalves, 7712, 91541-000 Porto Alegre - RS, Brasil

\title{
Robson Andreazza*
}

Centro de Engenharias, Universidade Federal de Pelotas, Rua Almirante Barroso 1734, 96010-280 Pelotas - RS / Departamento de Ciência do Solo, Universidade Federal do Rio Grande do Sul, Av. Bento Gonçalves, 7712, 91541-000 Porto Alegre - RS, Brasil Rodrigo Josemar Seminoti Jacques e Daiana Bortoluzzi Baldoni

Departamento de Ciência do Solo, Universidade Federal de Santa Maria, Av. Roraima 1000, 97105-900 Santa Maria - RS, Brasil Fátima M. Bento

Departamento de Microbiologia, Universidade Federal do Rio Grande do Sul, Av. Bento Gonçalves, 7712, 91541-000 Porto Alegre - RS, Brasil

Recebido em 23/1/12; aceito em 23/4/12; publicado na web em 20/7/2012

\begin{abstract}
This study aimed to evaluate the environmental conditions for enzyme activity of catechol 1,2-dioxygenase $(\mathrm{C} 1,2 \mathrm{O})$ and catechol 2,3-dioxygenase $(\mathrm{C} 2,3 \mathrm{O})$ produced by Gordonia polyisoprenivorans in cell-free and immobilized extracts. The optimum conditions of $\mathrm{pH}$, temperature, time course and effect of ions for enzyme activity were determined. Peak activity of $\mathrm{C} 1,2 \mathrm{O}$ occurred at $\mathrm{pH}$ 8.0. The isolate exhibited the highest activity of $\mathrm{C} 2,3 \mathrm{O}$ at $\mathrm{pH} 7.0$ and 8.0 for the cell-free extract and immobilized extract, respectively. This isolate exhibited important characteristics such as broad range of $\mathrm{pH}$, temperature and time course for enzyme activity.
\end{abstract}

Keywords: anthracene; enzyme activity; enzyme immobilization.

\section{INTRODUCTION}

Many polycyclic aromatic hydrocarbons (PAHs) are known to exhibit high toxicity and cancerous properties in humans and animals. ${ }^{1}$ Thus, studies on environmental contamination by PAH compounds have increased over recent years..$^{2-5}$ However, the bioremediation of $\mathrm{PAH}$-contaminated sites using the biodegradation technique is an efficient alternative for reducing these environmental problems.

The soil microorganisms are potential catalytic sources for biodegradation of organic compounds; however, PAHs are selective substances which provide a selective source of carbon as energy, and can promote a toxic effect in most microorganisms; therefore, the soil can be an important source of microorganisms for biodegradation of PAHs. ${ }^{6}$ However, it is necessary to determine the optimum environmental conditions of the efficien microorganisms for growth and to biodegrade different PAHs.

The use of microbial enzymes for biodegradation of toxic organic compounds such as PAH is promoting excellent results in the clean-up of different environments including water, ${ }^{7-9}$ sludge $^{2}$ and soil. ${ }^{10}$ The enzymes for degradation of PAHs can be divided into two groups: the peripheral group and fission group. ${ }^{11}$ The enzymes have a role in peripheral recognition and convert the degradable PAH molecules by enzymes in fission, allowing entry of these molecules to the common routes of energy generation and carbon in microbial cells. ${ }^{11}$

Catechol 1,2-dioxygenase (EC 1.13.11.1) has $\mathrm{Fe}^{3+}$ as a prosthetic group and belongs to the enzymes that perform intradiol cleavage. ${ }^{12}$ Many bacterial species do not have identical $\alpha$ and $\beta$ subunits $(\alpha \beta$ $\left.\mathrm{Fe}^{3+}\right)_{\mathrm{n}}$; while others have simple polypeptides $\left(\alpha \alpha-\mathrm{Fe}^{3+}\right)$ and present little or no activity to chloro-catechols. ${ }^{12}$ Catechol 2,3-dioxygenase (EC 1.13.11.2) however, belongs to the extradiol cleaving enzyme

*e-mail: robsonandreazza@yahoo.com.br class and has four identical subunits of $32 \mathrm{KDa}$ and contains a catalytic iron ion $\left(\mathrm{Fe}^{2+}\right)$ per subunit.

Some species of Gordonia have been used for biodegradation of organic compounds such as diesel, ${ }^{13}$ biodiesel,,${ }^{14}$ crude oil, ${ }^{15}$ some PAHs such as dibenzothiophene (DBT),${ }^{16}$ di-n-octyl phthalate, ${ }^{17}$ and some aliphatic and aromatic hydrocarbons. ${ }^{18}$ Although detection of catechol 1,2-dioxygenase produced by Gordonia spp. has been described, ${ }^{19}$ there is a paucity of studies investigating optimum environmental conditions for biodegradation of anthracene by Gordonia polyisoprenivorans. The enzyme activity of catechol 1,2-dioxygenase and catechol 2,3-dioxygenase can be an important tool for further use in biodegradation of PAHs.

Despite the many advantages of using enzymes in the bioremediation of wastewater, it has been observed that free enzymes tend to show low stability under certain environmental conditions. Therefore, immobilization technology has been widely used, improving activity, stability, specificity, selectivity while decreasing inhibition. ${ }^{19}$ The objective of this study was to evaluate environmental conditions that affect the activity of catechol 1,2-dioxygenase and catechol 2,3-dioxygenase from Gordonia polyisoprenivorans, in cell-free and immobilized extracts, for further bioremediation studies in wastewater treatment.

\section{EXPERIMENTAL}

\section{Microorganism, media and growth conditions}

An aromatic hydrocarbon degrading microbial consortium was obtained from the enrichment culture of a petrochemical landfarm. ${ }^{20}$ From this consortium, an isolate was characterized by the $16 \mathrm{~S}$ rRNA region as Gordonia polyisoprenivorans, and was used for further analysis.

This isolate was inoculated in Erlenmeyer flasks with Luria Bertani broth (LB) amended with $250 \mathrm{mg} \mathrm{L}^{-1}$ of anthracene as fine 
crystals (Merck ${ }^{\mathrm{TM}}$, Darmstadt, Germany). The LB broth medium comprised $5.0 \mathrm{~g} \mathrm{~L}^{-1}$ of meat extract; $10.0 \mathrm{~g} \mathrm{~L}^{-1}$ of tryptone; and $10.0 \mathrm{~g} \mathrm{~L}^{-1}$ of $\mathrm{NaCl}$. The $\mathrm{pH}$ was adjusted to 7.0 by adding aliquots of either $\mathrm{HCl}$ or $\mathrm{NaOH}$. The media were sterilized by autoclaving at $121^{\circ} \mathrm{C}$ for $20 \mathrm{~min}$. Flasks were incubated at $30{ }^{\circ} \mathrm{C}$ with orbital shaking $(150 \mathrm{rpm})$ with three replicates used for each individual experiment.

\section{Preparation of cell-free extract}

After growth for $36 \mathrm{~h}$, cells were harvested from LB by centrifugation $\left(10,000 \mathrm{rpm}\right.$, for $10 \mathrm{~min}$ at $\left.5{ }^{\circ} \mathrm{C}\right)$. The pellet was washed twice with phosphate buffer ( $50 \mathrm{mM}, \mathrm{pH} 7.0)$ and re-suspended in $10 \mathrm{~mL}$ of the same buffer. Suspensions were sonicated with repeated $40 \mathrm{~s}$ bursts alternated with 1 min cooling in ice. Cell debris was centrifuged at $12,000 \mathrm{rpm}$ for $15 \mathrm{~min}$. Supernatants (cell-free extract) were used for enzyme assays and immobilization as outlined below.

\section{Enzyme immobilization}

The enzyme was immobilized using the sodium alginate matrix technique. ${ }^{21}$ One milliliter of cell-free extract (9000 U) was suspended in $9 \mathrm{~mL}$ of $2 \%(\mathrm{w} / \mathrm{v})$ sodium alginate prepared in $50 \mathrm{mM}$ Tris- $\mathrm{HCl}$ buffer solution ( $\mathrm{pH}$ 8.0). After homogenization of the mixture, the enzyme was dripped into $100 \mathrm{~mL}$ of solution of $0.2 \mathrm{M}$ of $\mathrm{CaCl}_{2}$, using a pipette. Upon contact with the solution, the drops gelled to form defined-sized spheres ( $3 \mathrm{~mm}$ of diameter) which remained in the solution under gentle agitation to complete gel formation. After $1 \mathrm{~h}$ of incubation, the beads were removed, washed twice with sterile distilled water and stored at $4{ }^{\circ} \mathrm{C}$.

\section{Enzyme activity}

Catechol 1,2-dioxygenase activity in the cell-free and immobilized extracts was assayed spectrophotometrically with measurement of absorbance at $\lambda=260 \mathrm{~nm}$, corresponding to the formation of cis,cis-muconic acid. The reaction mixtures contained $1 \mathrm{~mL}$ of soluble or immobilized enzyme preparations; $1 \mathrm{~mL}$ of $0.8 \mathrm{mM}$ catechol; $0.8 \mathrm{~mL}$ of $50 \mathrm{mM}$ Tris-HCl buffer solution $(\mathrm{pH} 8.0)$ and $0.2 \mathrm{~mL}$ of $0.1 \mathrm{mM} 2$-mercaptoetanol. ${ }^{22}$ The activity of the cell-free and immobilized catechol 2,3-dioxygenase was determined spectrophotometrically with the measurement of absorbance at $\lambda=375 \mathrm{~nm}$, as described by Baggi et al.. ${ }^{23}$

The reaction mixtures contained $1 \mathrm{~mL}$ of soluble or immobilized enzyme preparation; $1 \mathrm{~mL}$ of $0.3 \mathrm{mM}$ catechol; and $0.8 \mathrm{~mL}$ of 50 $\mathrm{mM}$ phosphate buffer ( $\mathrm{pH}$ 7.0). All determinations were made in duplicate for each sample. After the addition of the enzymes (for both cell-free and immobilized extract), mixtures were incubated at $30{ }^{\circ} \mathrm{C}$ in a water-bath. At set time intervals, aliquots were used to monitor reaction progress in the spectrophotometer.

\section{Effect of pH, temperature and time course}

The optimum $\mathrm{pH}$ was determined by measuring activity at 30 ${ }^{\circ} \mathrm{C}$ over the $\mathrm{pH}$ range 4.0 to 9.0 , using the following buffers: 50 $\mathrm{mM}$ acetate ( $\mathrm{pH} 4.0,4.5,5.0$, and 5.5), $50 \mathrm{mM}$ phosphate ( $\mathrm{pH} 6.0$, 6.5, 7.0, 7.5 and 8.0) and $50 \mathrm{mM}$ Tris- $\mathrm{HCl}(\mathrm{pH} 7.0,7.5,8.0,8.5$ and 9.0). The optimum temperature was determined by assaying the enzyme activity at various temperatures (from 5 to $70{ }^{\circ} \mathrm{C}$ ) in $50 \mathrm{mM}$ Tris- $\mathrm{HCl}$ buffer solution ( $\mathrm{pH} \mathrm{8.0)}$ ). The time course of the enzyme activity was determined by measuring the activity in 50 $\mathrm{mM}$ Tris- $\mathrm{HCl}$ buffer solution $\left(\mathrm{pH} 8.0\right.$ ), at $30^{\circ} \mathrm{C}$ for $90 \mathrm{~min}$ with intervals of $10 \mathrm{~min}$.

\section{Effect of ions}

The ions tested were $\mathrm{Cu}^{2+}, \mathrm{Mg}^{2+}, \mathrm{Hg}^{2+}, \mathrm{Mn}^{2+}, \mathrm{Fe}^{2+}, \mathrm{K}^{+}$and $\mathrm{NH}_{4}^{+}$ at a concentration of $1.0 \mathrm{mM}$ for each ion and $10 \mathrm{mM}$ for $\mathrm{NH}_{4}^{+}$in $50 \mathrm{mM}$ Tris- $\mathrm{HCl}$ buffer solution ( $\mathrm{pH} \mathrm{8.0)}$ ), at $25{ }^{\circ} \mathrm{C}$ in cell-free and immobilized extracts. Ions were not added to the control or those in the buffer. The chemicals used were copper sulphate, magnesium chloride, mercury chloride, manganese chloride, iron chloride, potassium acetate and ammonium sulphate.

\section{RESULTS}

\section{Effect of pH}

The $\mathrm{pH}$ affected the enzyme activity of both enzymes catechol 1,2-dioxygenase $(\mathrm{C} 1,2 \mathrm{O})$ and catechol 2,3-dioxygenase $(\mathrm{C} 2,3 \mathrm{O})$ in the cell-free extract (Figure 1). The highest activity of $\mathrm{C} 1,2 \mathrm{O}$ was at $\mathrm{pH} 8.0$ in Tris- $\mathrm{HCl}$ buffer. In the phosphate buffer, the $\mathrm{C} 1,2 \mathrm{O}$ enzyme was high at $\mathrm{pH} 8.0$ achieving the highest relative activity of almost $100 \%$; on the other hand, the enzyme activity was low at $\mathrm{pH}$ levels lower than 5.5 (acetate buffer), showing sensitivity for $\mathrm{H}^{+}$presence in the solution. The activity of the enzyme $\mathrm{C} 2,3 \mathrm{O}$ was greatest at $\mathrm{pH} 7.0$ in the phosphate buffer. In Tris- $\mathrm{HCl}$, activity of the $\mathrm{C} 2,3 \mathrm{O}$ enzyme was highest at $\mathrm{pH} 7.5$; however, in the acetate buffer the $\mathrm{C} 2,3 \mathrm{O}$ activity produced by Gordonia was higher than $30 \%$, showing the capacity of this enzyme to adapt under different conditions for enzyme activity.

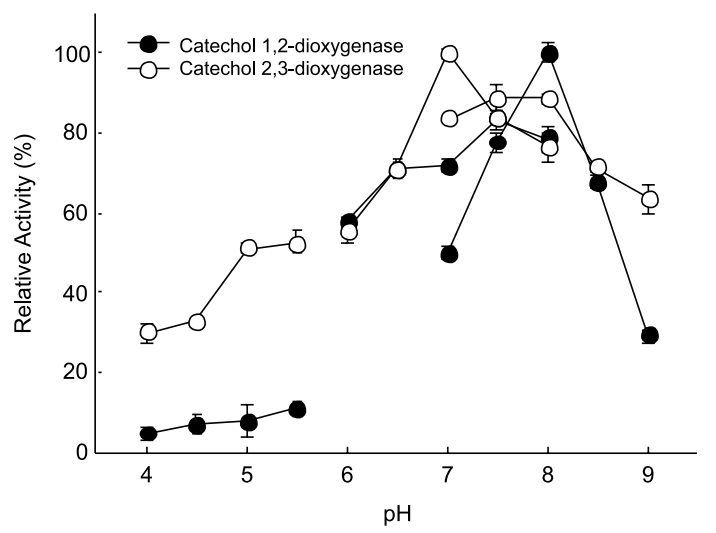

Figure 1. Effect of pH in the catechol 1,2-dioxygenase (black symbols) and catechol 2,3-dioxygenase (white symbols) activity of the cell free extract produced by Gordonia polyisoprenivorans. Buffers: acetate (from $\mathrm{pH} 4.0$ to 5.5), phosphate (from $\mathrm{pH} 6.0$ to 8.0), and tris- $\mathrm{HCl}$ (from $\mathrm{pH} 7.0$ to 9.0). Error bars are standard error of the mean

The activity of the enzyme $\mathrm{C} 2,3 \mathrm{O}$ produced by the isolate Gordonia polyisoprenivorans exhibited a different behavior with cell-free and immobilized extracts at different $\mathrm{pH}$ ranges (Figure 2). $\mathrm{C} 2,3 \mathrm{O}$ exhibited less interference in the enzyme activity at all extremes of $\mathrm{pH}$ range. The isolate showed the highest activity at $\mathrm{pH} 7.0$ with the cell-free extract, in the phosphate buffer. On the other hand, the immobilized extract showed the highest activity of the enzyme $\mathrm{C} 2,3 \mathrm{O}$ at $\mathrm{pH} 8.0$, also in the phosphate buffer; however, the enzyme $\mathrm{C} 2,3 \mathrm{O}$ showed high activity in a $\mathrm{pH}$ range of between 6.5 and 8.0 for both buffers, Tris- $\mathrm{HCl}$ and phosphate.

\section{Effect of temperature}

The different temperatures affected activity of both enzymes $\mathrm{C} 1,2 \mathrm{O}$ and $\mathrm{C} 2,3 \mathrm{O}$; however, the different temperatures promoted similar behaviors for both enzymes (Figure 3 ). The activity of $\mathrm{C} 2,3 \mathrm{O}$ 


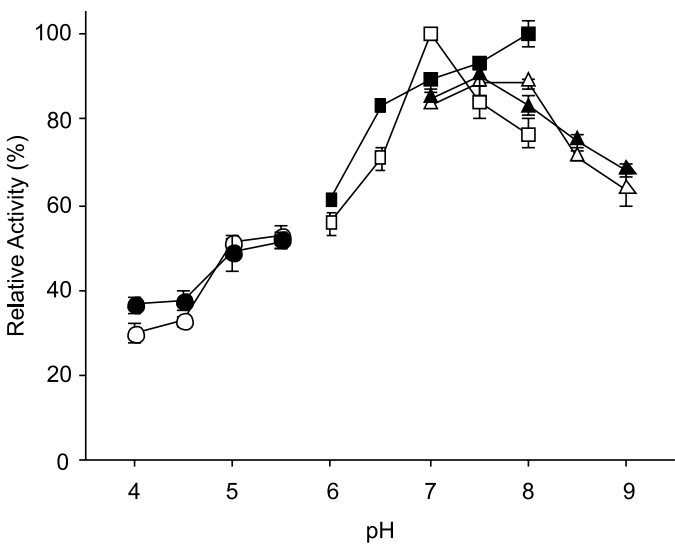

Figure 2. pH effect in the catechol 2,3-dioxigenase activity in the cell free extract (white symbols) and immobilized extract (black symbols) of Gordonia polyisoprenivorans. Buffers: acetate (from $\mathrm{pH} 4.0$ to 5.5 - cycle symbols), phosphate (from $\mathrm{pH} 6.0$ to 8.0 - square symbols), and Tris- $\mathrm{HCl}$ (from $\mathrm{pH} 7.0$ to 9.0 - triangle symbols) Error bars are standard error of the means

peaked at a temperature of $30^{\circ} \mathrm{C}$, and the enzyme $\mathrm{C} 1,2 \mathrm{O}$ at $25^{\circ} \mathrm{C}$. Upon comparing the two enzymes $(\mathrm{C} 1,2 \mathrm{O}$ and $\mathrm{C} 2,3 \mathrm{O})$, it is notable that $\mathrm{C} 2,3 \mathrm{O}$ exhibited a higher relative activity than $\mathrm{C} 1,2 \mathrm{O}$ across all temperatures, differing only for the optimum temperature. However, $\mathrm{C} 2,3 \mathrm{O}$ showed high relative activity of 45 and $37 \%$ at 45 and $50{ }^{\circ} \mathrm{C}$, respectively, showing a high potential to oxidize aromatic rings at high temperatures whereas $\mathrm{C} 1,2 \mathrm{O}$ did not exhibit the same results.



Figure 3. Effect of different temperatures in the activity of the catechol 1,2-dioxygenase $(\bullet)$ and catechol 2,3-dioxygenase $(\bigcirc)$ produced by the Gordonia polyisoprenivorans of the cell free extract. Error bars are the standard error of the means

The immobilization of $\mathrm{C} 2,3 \mathrm{O}$ produced by the Gordonia polyisoprenivorans promoted the highest activity at $50{ }^{\circ} \mathrm{C}$, which is $20^{\circ} \mathrm{C}$ higher than the cell-free extract with the same relative activity (Figure 4). Furthermore, the immobilization of the enzyme $\mathrm{C} 2,3 \mathrm{O}$ increased activity at high temperatures. For both cell-free and immobilized extracts, $\mathrm{C} 2,3 \mathrm{O}$ exhibited high enzyme activity; however, temperatures lower than $25{ }^{\circ} \mathrm{C}$ drastically decreased $\mathrm{C} 2,3 \mathrm{O}$ activity for the immobilized extract. In summary, the immobilization of the enzyme $\mathrm{C} 2,3 \mathrm{O}$ increased stability and the temperature range with high enzyme activity.

\section{Time course}

Enzymatic activity for both $\mathrm{C} 1,2 \mathrm{O}$ and $\mathrm{C} 2,3 \mathrm{O}$ decreased with the time course (Figure 5). C1,2O was more sensitive with the time course than enzyme $\mathrm{C} 2,3 \mathrm{O}$. The enzyme $\mathrm{C} 1,2 \mathrm{O}$ exhibited activity

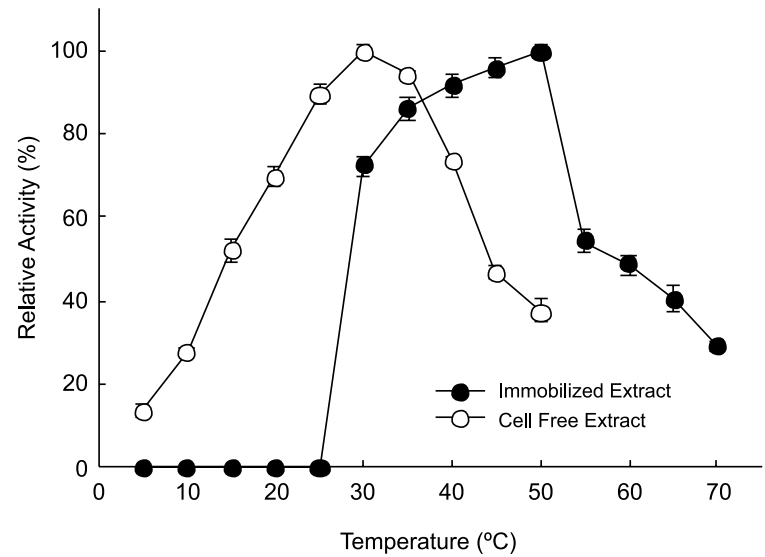

Figure 4. Effect of different temperatures in the activity of catechol 2,3-dioxygenase $(C 2,3 O)$ produced by the Gordonia polyisoprenivorans in the cell free extract $(\mathrm{O})$ and immobilized extract $(\bullet)$. Data are mean of two replicates; error bars represent standard error

for $60 \mathrm{~min}$, maintaining high activity during the first $30 \mathrm{~min}$ losing only $10 \%$ of the initial relative activity. After 40 min of incubation, relative activity was less than $40 \%$, further decreasing until $60 \mathrm{~min}$. The enzyme $\mathrm{C} 2,3 \mathrm{O}$ exhibited the highest stability, with relative activity during the entire time course. However, at $30 \mathrm{~min}$ of incubation, enzymatic activity had lost $48 \%$ of the initial relative activity, and after $60 \mathrm{~min}$, the level of activity was very low (22\%) where it remained until the end of the experiment.

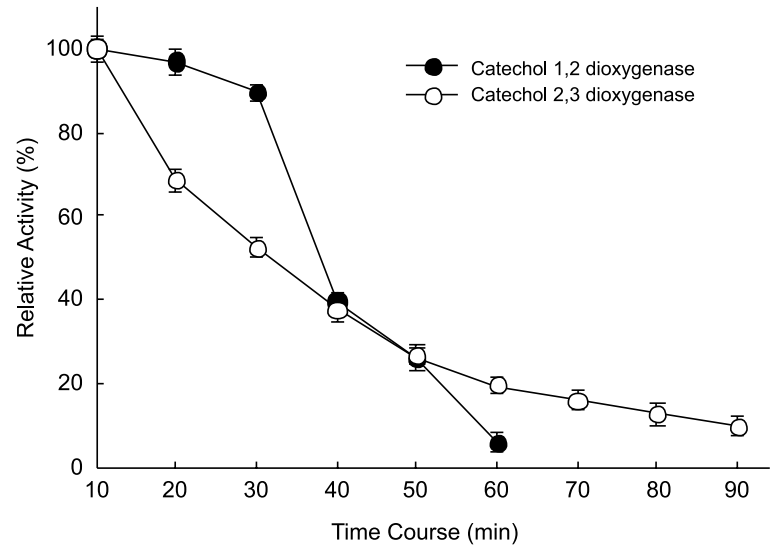

Figure 5. Time course of the catechol 1,2-dioxygenase $(\mathrm{O})$ and catechol 2,3-dioxygenase (-) enzyme activity in the cell free extract of the Gordonia polyisoprenivorans. Error bars are the standard error of the means

The cell-free extract and immobilized extract showed the same behavior in enzyme activity for $\mathrm{C} 2,3 \mathrm{O}$ produced by Gordonia polyisoprenivorans during the time course (Figure 6). However, the cell-free extract of the $\mathrm{C} 2,3 \mathrm{O}$ enzyme showed higher activity than the immobilized extract during the 90 min of incubation.

\section{Effect of ions}

The activity of both enzymes $\mathrm{C} 1,2 \mathrm{O}$ and $\mathrm{C} 2,3 \mathrm{O}$ was affected differently for the cations added (Figure 7a). The presence of $\mathrm{K}^{+}$and $\mathrm{Cu}^{2+}$ inhibited $25 \%$ of the enzyme activity for both enzymes $\mathrm{C} 1,2 \mathrm{O}$ and $\mathrm{C} 2,3 \mathrm{O}$. The presence of $\mathrm{Hg}^{2+}$ ions in the reaction mixture of $\mathrm{C} 2,3 \mathrm{O}$ inhibited $22 \%$ of enzyme activity, yet the same metal boosted the activity of $\mathrm{C} 1,2 \mathrm{O}$ by $12 \%$. On the other hand, the presence of $\mathrm{Mg}$ ions inhibited the activity of $\mathrm{C} 1,2 \mathrm{O}$ by $28 \%$, and stimulated the 




Figure 6. Time course of the catechol 2,3-dioxygenase (C2,3O) produced by the Gordonia polyisoprenivorans in the cell free extract $(\mathrm{O})$ and immobilized extract $(\bullet)$. Error bars are the standard error of the means

activity of $\mathrm{C} 2,3 \mathrm{O}$ by $23 \%$ of the relative activity. The addition of the $\mathrm{Fe}^{3+}, \mathrm{Mn}^{2+}$ and $\mathrm{NH}_{4}{ }^{+}$cations stimulated the enzyme activity of both enzymes. Mn showed the highest stimulation for both enzymes, with almost $100 \%$ stimulation for the $\mathrm{C} 1,2 \mathrm{O}$ enzyme, and $132 \%$ stimulation for the $\mathrm{C} 2,3 \mathrm{O}$ enzyme.
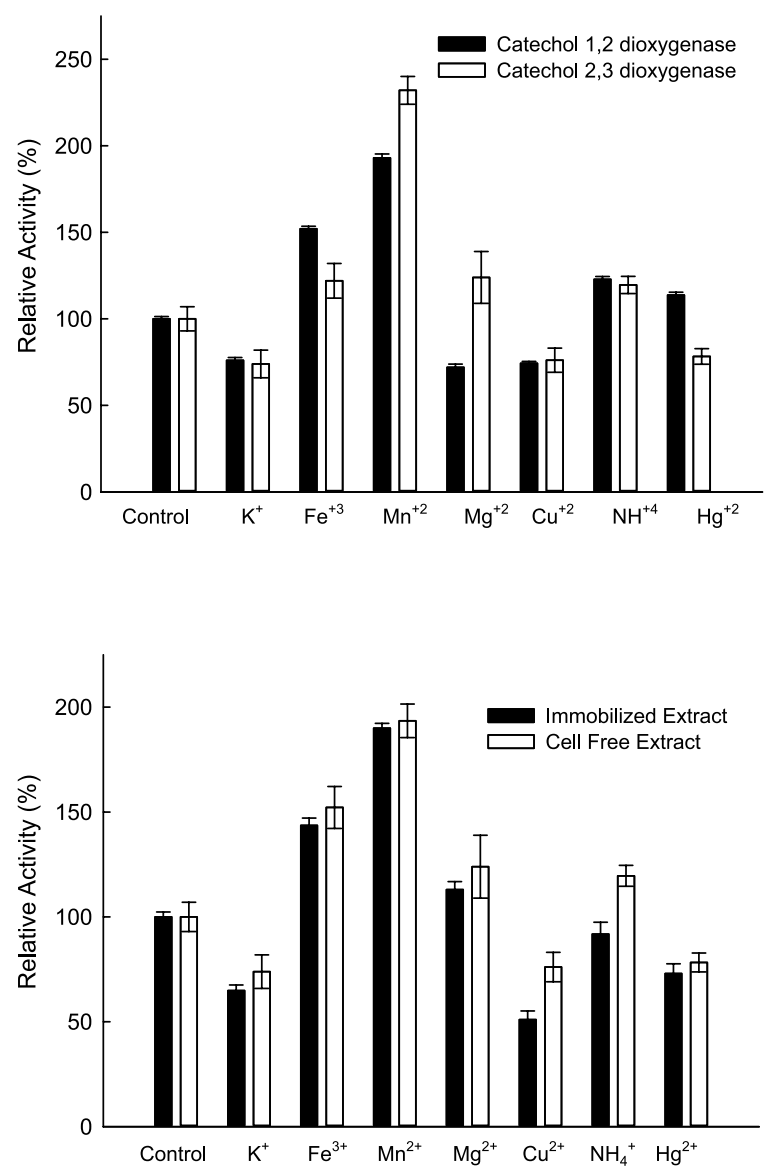

Figure 7. Effect of ions in relative enzymatic activity of the catechol 1,2-dioxygenase $(C 1,2 \mathrm{O})$ and catechol 2,3-dioxygenase $(C 2,3 \mathrm{O})$ in the cell free extract (a); and in the cell free extract (white columns) and immobilized extract (black columns) (b) produced by the Gordonia polyisoprenivorans. Error bars are the standard error of the means. The control treatment is the enzyme activity in the absence of the ions
The activity of $\mathrm{C} 2,3 \mathrm{O}$ produced by Gordonia polyisoprenivorans showed the same behavior for both cell-free and immobilized extracts in the presence of the different cations $\mathrm{K}^{+}, \mathrm{Mg}^{2+}, \mathrm{NH}_{4}{ }^{+}, \mathrm{Hg}^{2+}$, and $\mathrm{Mn}^{2+}$ (Figure 7b). However, the cell-free extract showed slightly greater activity for all treatments, compared with the immobilized extract. The immobilization of $\mathrm{C} 2,3 \mathrm{O}$ did not exhibit protection against the deleterious effects of $\mathrm{Hg}^{2+}, \mathrm{K}^{+}$and $\mathrm{Cu}^{2+}$ ions, and even promoted the activity with most of the cations with the exception of iron. The greatest difference obtained was for the presence of $\mathrm{Cu}^{2+}$, which showed $51 \%$ of relative activity in the immobilized extract versus $76 \%$ for the cell-free extract.

\section{DISCUSSION}

Gordonia polyisoprenivorans was first isolated degrading polymers of rubber from used tires. ${ }^{24}$ This microorganism is an actinomycete that forms hyphae, which by breaking the down produces rod-shaped or coccus cells. Several studies have reported the use of this specie in the degradation of aliphatic compounds, ${ }^{25}$ crude oil,${ }^{15,26}$ diesel, ${ }^{13}$ biodiesel,,${ }^{14}$ some PAHs ${ }^{16,27}$ and di-n-octyl phthalate. ${ }^{17}$ However, there is a paucity of studies on enzyme degradation use by Gordonia for bioremediation. Furthermore, there are few studies on dioxygenases produced by actinomycetes in the treatment of waste contaminated with aromatic pollutants.

In this study of enzymatic activity, two routes for degradation of anthracene via ortho and meta pathways were identified for which the activity of the enzymes catechol 1,2-dioxygenase $(\mathrm{C} 1,2 \mathrm{O})$ and catechol 2,3-dioxygenase $(\mathrm{C} 2,3 \mathrm{O})$ was quantified. In this study, environmental conditions that affect the activity of catechol 1,2-dioxygenase $(\mathrm{C} 1,2 \mathrm{O})$ and catechol 2,3-dioxygenase $(\mathrm{C} 2,3 \mathrm{O})$ from Gordonia polyisoprenivorans were assessed in cell-free extract and immobilized extract. According to the results obtained, there was a predominance of the enzyme $\mathrm{C} 2,3 \mathrm{O}$ produced by the isolated $G$. polyisoprenivorans. This may be related to the economy of energy by the bacteria which decreases the production of the enzyme $\mathrm{C} 1,2 \mathrm{O}$ and is part of a more complex route for degradation. ${ }^{28}$

The enzyme activity of $\mathrm{C} 2,3 \mathrm{O}$ was higher than that of $\mathrm{C} 1,2 \mathrm{O}$ under most of the environmental conditions tested. $\mathrm{H}^{+}$concentration affects enzyme activity in various ways. One way to be considered is that the catalytic process requires this enzyme, with specific catalytic groups in an ionized or non-ionized state, to interact with the substrate without alteration in its active conformation and stability of enzymes. Consequently, it does not drastically reduce its activity. ${ }^{29}$ The enzyme can be immobilized on a solid support, such as sodium alginate and thus the optimum $\mathrm{pH}$ tends to increase by two units. ${ }^{30}$ This increase is due to the fact that the surface of the immobilized enzyme concentration of $\mathrm{H}^{+}$ions is greater than the concentration of $\mathrm{H}^{+}$ions in the solution where the $\mathrm{pH}$ is measured. Thus, the enzyme activity of the $\mathrm{C} 2,3 \mathrm{O}$ isolate of $G$. polyisoprenivorans in the cell-free extract showed higher activity at $\mathrm{pH} 7.0$ in phosphate buffer, whereas the immobilized extract showed the highest activity of this enzyme in the phosphate buffer at $\mathrm{pH}$ 8.0.

Enzyme activity is dependent upon temperature. ${ }^{29}$ Most enzymes have an optimum temperature which can be related to the temperature of the environment in which microorganisms were isolated. ${ }^{31}$ Other enzymes, such as copper reductase, are also influenced by different temperatures. ${ }^{32,33}$ At low temperatures the movement of the molecules is slow and no activity is required to convert the substrate into a product, while at higher temperatures, the thermal movement of the molecules is too high to ensure enzyme conformation, thus causing their denaturation and activity loss. ${ }^{29}$ Fernandez-Lafuente et al..$^{34}$ determined the optimum temperature for the activity of the enzyme $\mathrm{C} 2,3 \mathrm{O}$ as $50{ }^{\circ} \mathrm{C}$, where the enzyme was produced by Bacillus 
stearothermophilus and showed optimum growth at $55^{\circ} \mathrm{C}$.

The enzyme $\mathrm{C} 1,2 \mathrm{O}$ showed the lowest activity at $5^{\circ} \mathrm{C}$. This activity increased to achieve an optimum temperature at $25^{\circ} \mathrm{C}$. At $35^{\circ} \mathrm{C}$, relative activity was $40 \%$, with activity close to zero at temperatures above $45^{\circ} \mathrm{C}$. This demonstrates that the enzyme has a well-defined optimum temperature, and a small variation above or below this value can generate substantial activity losses. Similar results were found by Kalogeris et al. ${ }^{35}$ when evaluating the enzyme activity of $\mathrm{C} 1,2 \mathrm{O}$ produced by Pseudomonas putida.

The time course of enzyme activity is an important and very practical issue; since this evaluation enables determination of the time required for the substrate to be converted into a product. ${ }^{29}$ Immobilization is due to implementing a support that modifies the micro-environment in which the enzyme works. ${ }^{36}$ However, immobilized enzymes may have low enzyme activity compared to free enzymes, allowing greater catalytic efficiency of enzymes, as well as defining their kinetic properties and stability. ${ }^{37}$ Thus, the application of nutrients did not increase the activity of immobilized extract, probably due to lower diffusion through the solid barrier (sodium alginate), where the same occurred with inhibitors, confirming the theory that immobilized enzymes may have lower activity due to reduced availability of nutrients, but greater stability as they are less affected by inhibitors compared to their free form. ${ }^{36}$ Our results corroborated this notion, where the cell-free extract exhibited higher activity than the immobilized extract under many of the environmental conditions tested.

In many proteins, metal ions interactions play catalytic roles whereas in others the metals appear to have a purely structural role. Independently of enzyme $(\mathrm{C} 1,2 \mathrm{O}$ or $\mathrm{C} 2,3 \mathrm{O})$ and cellular extract (free or immobilized), $\mathrm{Mn}^{2+}$ and $\mathrm{Fe}^{3+}$ ions stimulated enzyme activity. Conversely, $\mathrm{K}^{+}$and $\mathrm{Cu}^{+2}$ ions inhibited enzymatic activity. Other studies have showned that manganese as a divalent cation is present in the structure of enzymes as well as iron dioxygenases, but in smaller proportions, especially for enzymes with intradiol cleavage, i.e. catechol 1,2-dioxygenase and protocatechol 3,4-dioxygenase. ${ }^{38}$ This fact can be explained by the chemical properties of manganese compared to iron II or iron III properties for this ion, such as a core element that indicates the specific location of the addition of $\mathrm{O}_{2}$, producing the opening of an aromatic ring..$^{39}$ Both types of catechol dioxygenase contain an active-site iron that is essential for enzyme activity. ${ }^{39}$ At the adequate concentration in mineral medium, the iron improved PAH degradation by Pseudomonas isolates. ${ }^{40}$ In relation to the effect of $\mathrm{Cu}^{+2}$, many studies have shown inhibition promoted by this element in enzymatic systems. Copper has been shown to drastically inhibit catechol dioxygenases activity produced by $P$. putida ${ }^{41}$ Geobacillus sp. ${ }^{23}$ and Alcaligenes xylosoxidans. ${ }^{42}$

\section{CONCLUSIONS}

The enzyme activity of catechol 2,3-dioxygenase in the cell-free extract was higher than catechol 1,2-dioxygenase under most of the environment conditions evaluated. Catechol 2,3-dioxygenase exhibited higher activity in upper and lower $\mathrm{pH}$ ranges, at higher temperatures, and maintained activity over a broad time course. Enzyme activity stimulus and inhibitions were similar for both enzymes with presence of ions in the reaction mixture. The immobilization of catechol 2,3-dioxygenase did not result in higher activity for this enzyme in the peaks of $\mathrm{pH}$, low temperatures and presence of toxic ions. Nevertheless, enzyme activity steadily increased with higher temperatures. Both enzymes catechol 1,2-dioxygenase and catechol 2,3-dioxygenase produced by Gordonia polyisopre showed activity over a wide range of environmental conditions and exhibited great potential for use in bioremediation techniques applied to liquid waste contaminated with aromatic pollutants.

\section{ACKNOWLEDGEMENTS}

This project was supported by CAPES (Coordenação de Aperfeiçoamento de Pessoal de Nível Superior) and CNPq (Conselho Nacional de Desenvolvimento Científico e Tecnológico), Brazil.

\section{REFERENCES}

1. Costantini, A. S.; Gorini, G.; Consonni, D.; Miligi, L.; Giovannetti, L.; Quinn, M.; Tumori 2009, 95, 8.

2. Barret, M.; Carrère, H.; Delgadillo, L.; Patureau, D.; Water Res. 2010 , 44, 3797.

3. Dissanayake, A.; Bamber, S. D.; Mar. Environ. Res. 2010, 70, 65.

4. Engraff, M.; Solere, C.; Smith, K. E. C.; Mayer, P.; Dahllöf, I. ; Aquat. Toxicol. 2011, 102, 142.

5. Herold, M.; Greskowiak, J.; Ptak, T.; Prommer, H.; J. Contam. Hydrol. 2011, 119, 99 .

6. Alexander, M.; Biodegradation and Bioremediation, Academic Press: New York, 1999.

7. Guo, C.; Dang, Z.; Wong, Y.; Tam, N. F.; Int. Biodeter. Biodegr. 2010, $64,419$.

8. Wang, C.; Wang, F.; Wang, T.; Bian, Y.; Yang, X.; Jiang, X.; J. Hazard. Mater. 2010, 176, 41.

9. Zhao, Z.; Selvam, A.; Wong, J. W.; Bioresour. Technol. 2011, 102, 3999.

10. Moon, H. S.; Kahng, H. Y.; Kim, J. Y.; Kukor, J. J.; Nam, K.; Environ. Pollut. 2006, 140, 536.

11. Mishra, V.; Rup, L.; Srinivasan, A.; Crit. Rev. Microbiol. 2001, 27, 133.

12. Harayama, S.; Ann. Rev. Microbiol. 1992, 46, 565.

13. Lee, Y.; Shin, H.; Ahn, Y.; Shin, M.; Lee, M.; Yang, J.; J. Hazard. Mater. 2010, 183,940 .

14. Lee, M.; Kim, M. K.; Kwon, M.; Park, B. D.; Kim, M. H.; Goodfellow, M.; Lee, S.; J. Biosci. Bioeng. 2005, 100, 429.

15. Díaz-Ramírez, I. J.; Escalante-Espinosa, E.; Favela-Torres, E.; GutiérrezRojas, M.; Ramírez-Saad, H.; Int. Biodeter. Biodegr. 2008, 62, 21.

16. Jia, X.; Wen, J.; Sun, Z.; Caiyin, Q.; Xie, S.; Chem. Eng. Sci. 2006, 61, 1987.

17. Wu, X.; Liang, R.; Dai, Q.; Jin, D.; Wang, Y.; Chao, W.; J. Hazard. Mater. 2010, 176, 262.

18. Franzetti, A.; Caredda, P.; Ruggeri, C.; Colla, P. L.; Tamburini, E.; Papacchini, M.; Bestetti, G.; Chemosphere 2009, 75, 801.

19. Shen, F.; Lin, J.; Huang, C.; Ho, Y.; Arun, A. B.; Young, L.; Young, C.; System. Appl. Microbiol. 2009, 32, 291.

20. Jacques, R. J. S.; Okeke, B. C.; Bento, F. M.; Peralba, M. C. R.; Camargo, F. A. O.; Biorem. J. 2007, 11, 1.

21. Giedraityte, G.; Kalèdienè, L.; Cent. Eur. J. Biol. 2009, 4, 68.

22. Hegman, G. D.; J. Bacteriol. 1966, 91, 1140.

23. Baggi, G.; Barbieri, P.; Galli, E.; Tollari, S.; Appl. Environ. Microbiol. 1987, 53, 2129

24. Linos, A.; Steinbüchel, A.; Spröer, C.; Kroppenstedt, R. M.; Int. J. System. Bacteriol. 1999, 49, 1785.

25. Linos, A.; Berekaa, M. M.; Reichelt, R.; Keller, U.; Schmitt, J.; Flemming, H.; Kroppenstedt, R. M.; Steinbüchel, A.; Appl. Environ. Microbiol. 2000, 66, 1639.

26. Chaillan, F.: Flèche, A. L.; Bury, E.; Phantavong, Y.; Grimont, P.; Saliot, A.; Oudot, J.; Res. Microbiol. 2004, 155, 587.

27. Mutnuri, S.; Vasudevan, N.; Kaestner, M.; Appl. Microbiol. Biotechnol. 2005, 67, 569 .

28. Burlage, R. S.; Hooper, S. W.; Sayler, G. S.; Appl. Environ. Microbiol. 1989, 55, 1323

29. Whiteley, C. G.; Lee, J. D.; Enzyme Microb. Technol. 2006, 38, 291.

30. Gianfreda, L.; Bollag, J. M. In Enzymes in the Environment: Activity, Ecology and Application; Burns, R. G.; Dick, R. P., eds.; Marcel Dekker: New York, 2002. 
31. Atlas, R.M.; Bartha, R.; Microbial Ecology: Fundamental and Applications, Academic Press: Menlo Park, 1997.

32. Andreazza, R.; Pieniz, P.; Wolf, L.; Lee, M.; Camargo, F. A. O.; Okeke, B. C.; Sci. Total Environ. 2010, 408, 1501.

33. Andreazza, R.; Okeke, B. C.; Pieniz, P.; Brandelli, A.; Lambais, M. R.; Camargo, F. A. O.; Biol. Trace Elem. Res. 2011, 143, 1182.

34. Fernandez-Lafuente, R.; Guisan, J. M.; Ali, S.; Cowan, D.; Enzyme Microb. Technol. 2000, 26, 568.

35. Kalogeris, E.; Sanakis, Y.; Mamma, D.; Christakopoulos, P.; Kekos, D.; Stamatis, H.; Enzyme Microb. Technol. 2006, 39, 1113.

36. Krajewska, B.; Enzyme Microb. Technol. 2004, 35, 126.
37. Degaldillo, R.; Roduguez-Nogales, J. M.; J. Mol. Catal. B: Enzym. 2005, $33,15$.

38. Whiting, A. K.; Boldt, Y. R.; Hendrich, M. P.; Wackett, L. P.; Que, L.; Biochemistry 1996, 35, 160.

39. Bohdziewicz, J.; Process Biochem. 1998, 33, 811.

40. Santos, E. C.; Jacques, R. J. S.; Bento, F. M.; Peralba, M. C. R.; Selbach, P. A.; Sá, E. L. S.; Camargo, F. A. O.; Bioresour. Technol. 2008, 99, 2644.

41. Wang, C. L.; You, S. L.; Wang, S. L.; Process Biochem. 2006, 41, 1594.

42. Yeom, S. H.; Yoo, Y. J.; Process Biochem. 1999, 34, 281. 